\title{
Bacillus novalis sp. nov., Bacillus vireti sp. nov., Bacillus soli sp. nov., Bacillus bataviensis sp. nov. and Bacillus drentensis sp. nov., from the Drentse A grasslands
}

\author{
Jeroen Heyrman, ${ }^{1}$ Bram Vanparys, ${ }^{1}$ Niall A. Logan, ${ }^{2}$ An Balcaen, ${ }^{1}$ \\ Marina Rodríguez-Díaz, ${ }^{2}$ Andreas Felske ${ }^{3}$ and Paul De Vos $^{1}$ \\ ${ }^{1}$ Ghent University, Department BFM (WE10V), Laboratory of Microbiology, \\ K.-L. Ledeganckstraat 35, B-9000 Gent, Belgium \\ ${ }^{2}$ School of Biological and Biomedical Sciences, Glasgow Caledonian University, Cowcaddens \\ Road, Glasgow G4 OBA, UK \\ ${ }^{3} \mathrm{GBF}$ (German Research Centre for Biotechnology), Division of Microbiology, Mascheroder \\ Weg 1, D-38124 Braunschweig, Germany
}

\begin{abstract}
A group of 42 isolates were isolated from the soil of several disused hay fields, in the Drentse A agricultural research area (The Netherlands), that were taken out of production at different times. The group represents hitherto-uncultured Bacillus lineages that have previously been found, by a non-cultural method, to be predominant in soil. The strains were subjected to a polyphasic taxonomic study, including (GTG) 5 -PCR, 16S rDNA sequence analysis, DNA-DNA hybridizations, DNA base-ratio determination, fatty acid analysis and morphological and biochemical characterization. By comparing the groupings obtained by (GTG) $)_{5}-P C R$ and $16 S$ rDNA sequence analysis, six clusters of similar strains could be recognized. A DNA-DNA relatedness study showed that these clusters represented five novel genospecies. Further analysis supported the proposal of five novel species in the genus Bacillus, namely Bacillus novalis sp. nov. (type strain IDA3307 $7^{\top}=\mathrm{R}-15439^{\top}=$ LMG $21837^{\top}=\mathrm{DSM} 15603^{\mathrm{T}}$ ), Bacillus vireti sp. nov. (type strain IDA3632 ${ }^{\top}=\mathrm{R}-15447^{\top}=$ LMG $21834^{\top}=\mathrm{DSM} 15602^{\top}$ ), Bacillus soli sp. nov. (type strain IDA0086 ${ }^{\top}=\mathrm{R}-16300^{\top}=$ LMG $21838^{\top}=\mathrm{DSM} 15604^{\top}$ ), Bacillus bataviensis sp. nov. (type strain IDA $1115^{\top}=\mathrm{R}-16315^{\top}=\mathrm{LMG} 21833^{\top}=\mathrm{DSM} 15601^{\top}$ ) and Bacillus drentensis sp. nov. (type

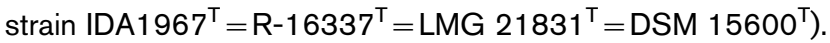

\section{INTRODUCTION}

The Drentse A agricultural research area, along the Anlooër Diepje brook near Anloo (The Netherlands), comprises different plots, some of which are still used for agriculture and some of which have been taken out of production at different times from the late 1960s onwards. The bacterial communities in different soil samples taken from these sites were previously studied by a culture-independent approach based on temperature-gradient gel electrophoresis (Felske \&

Published online ahead of print on 13 June 2003 as DOI 10.1099/ ijs.0.02723-0.

Abbreviations: rep-PCR, repetitive sequence-based PCR; $S_{G}$, Gower similarity coefficient.

The EMBL accession numbers for the 16S rRNA gene sequences of Bacillus novalis LMG $21837^{\top}$, Bacillus vireti LMG $21834^{\top}$, Bacillus soli LMG 21838', Bacillus bataviensis LMG 21833 ${ }^{\top}$ and Bacillus drentensis LMG $21831^{\top}$ are respectively AJ542512, AJ542509, AJ542513, AJ542508 and AJ542506.
Akkermans, 1998). It was demonstrated that the spatial distribution of bacterial $16 \mathrm{~S}$ rRNA from ribosomes directly extracted from soil was homogeneous among samples that represented a stretch of $1.5 \mathrm{~km}$ of the grassland. This suggested the presence of predominant bacteria occurring throughout the entire research area. Additional research by Felske et al. (1998) revealed that hitherto-uncultured Bacillus species were the most active bacteria, with approximately half of the sequenced $16 \mathrm{~S}$ rRNA being attributable to this genus. Felske et al. (1999) made a first attempt to culture these dominant lineages of Bacillus. They compared the band positions of 659 isolates in temperaturegradient gel electrophoresis with those of the dominant uncultured bacteria. Initially, approximately $8 \%$ of the isolates had band positions identical to those of one of the uncultured ribotypes. However, sequence analysis ( $\sim 500 \mathrm{bp}$ ) of these matching isolates indicated that their $16 \mathrm{~S}$ rDNA sequences were clearly different from sequences representing the fingerprint bands. Although the apparently 
predominant taxa could not be retrieved from this culture collection, a remarkable variety of bacilli, including novel species, were isolated. Thousands of strains were isolated from the soils; here, we report on 42 isolates that represent novel Bacillus species. They were all most closely related to Bacillus niacini, albeit with relatively low sequence similarities $(97 \cdot 5-99 \cdot 0 \%)$. After polyphasic characterization, this group of isolates could be recognized as members of five novel species within the genus Bacillus, which we propose as Bacillus novalis sp. nov., Bacillus vireti sp. nov., Bacillus soli sp. nov., Bacillus bataviensis sp. nov. and Bacillus drentensis sp. nov.

\section{METHODS}

Strains and media. The isolates originate from the Drentse A agricultural research area $\left(06^{\circ} 41^{\prime} \mathrm{E}, 53^{\circ} 02^{\prime} \mathrm{N}\right)$ in The Netherlands, a $1.5 \mathrm{~km}$ stretch of grassland alongside the Anlooër Diepje brook. Soil sampling, enrichment and cultivation were performed as described by Felske et al. (1999). All isolates originated from a general sample that was prepared by mixing together pooled samples from six plots representing different years during which fertilizer treatment for agricultural hay production had last occurred. Two dilution series were made of the sample; one series was plated directly on agar media and the other was plated after heating for $15 \mathrm{~min}$ at $80^{\circ} \mathrm{C}$ to select for endospores. The isolate designations and culture conditions applied are shown in Table 1. Isolates were further maintained on nutrient-agar slopes and maintained in Microbank tubes (Pro-Lab Diagnostics) at $-80^{\circ} \mathrm{C}$. For phenotypic-characterization studies, including microscopy, cultures were maintained on slopes of trypticase soy agar (TSA) containing $5 \mathrm{mg} \mathrm{MnSO}_{4} \mathrm{l}^{-1}$ (to enhance sporulation); for strains IDA3120, IDA3351 and IDA3632 ${ }^{\mathrm{T}}$, spore formation was determined on Bacillus fumarioli agar adjusted to $\mathrm{pH} 7 \cdot 0$ (Logan et al., 2000).

DNA preparation. Total genomic DNA was purified for $16 \mathrm{~S}$ rDNA sequencing and repetitive sequence-based PCR (rep-PCR) by using a slight modification of the method of Pitcher et al. (1989), as described by Heyndrickx et al. (1996). For determination of the $\mathrm{G}+\mathrm{C}$ content and DNA-DNA hybridization, approximately $1 \mathrm{~g}$ biomass was harvested from agar plates. DNA was purified by a combination of the protocols of Marmur (1961) and Pitcher et al. (1989), as described by Logan et al. (2000).

165 rDNA sequencing and phylogenetic analysis. Sequence analysis was performed as described previously by Heyrman \& Swings (2001). For partial sequencing, two primers were used (reverse 358-339 and reverse 536-519; Heyrman \& Swings, 2001) to obtain the first 400-500 bp of the 16S rRNA gene, which, according to Goto et al. (2000), includes the hypervariable region for the genus Bacillus. A phylogenetic tree was constructed using BioNumerics 2.0 software (Applied Maths) by applying the neighbour-joining method of Saitou \& Nei (1987) on a multiple-alignment similarity matrix. The stability of relationships was assessed by means of a bootstrap analysis of 1000 datasets.

Rep-PCR genomic fingerprinting. PCR was performed with the $(\mathrm{GTG})_{5}$ primer (Versalovic et al., 1994) using the PCR conditions described previously by Rademaker \& de Bruijn (1997). For each strain, $6 \mu \mathrm{l}$ PCR product mixed with $2 \mu$ l loading buffer (Rademaker \& de Bruijn, 1997) was electrophoresed in a $1.5 \%(w / v)$ agarose gel

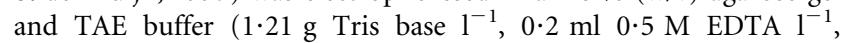
$\mathrm{pH} 8)$ for $15 \mathrm{~h}$ at a constant $55 \mathrm{~V}$ and $4{ }^{\circ} \mathrm{C}$. The first lane and every sixth lane were loaded with $6 \mu \mathrm{l}$ molecular ruler $[45 \cdot 5 \%(\mathrm{v} / \mathrm{v})$ 100 bp ruler (Bio-Rad), 36.5\% (v/v) 500 bp ruler (Bio-Rad) and
$18 \%(\mathrm{v} / \mathrm{v})$ loading buffer]. After staining with ethidium bromide $\left(0.5 \mu \mathrm{g} \mathrm{ml}^{-1}\right)$, the patterns were digitized and Pearson's correlation of the resulting band patterns was calculated using BioNumerics 2.0.

G+C content and DNA-DNA hybridization. The $\mathrm{G}+\mathrm{C}$ content of the DNA was determined by HPLC (Mesbah et al., 1989) using the further specifications given by Logan et al. (2000). DNA-DNA hybridization was performed using a modification of the microplate method of Ezaki et al. (1989), as described by Willems et al. (2001). A hybridization temperature of $40^{\circ} \mathrm{C}$ (calculated with correction for the presence of $50 \%$ formamide) was used.

Chemotaxonomic characterization. GC analysis of fatty acid methyl esters was performed starting from strains grown on TSA for $24 \mathrm{~h}$ at $28^{\circ} \mathrm{C}$. A quantitative analysis of cellular fatty acid compositions was further performed by using a GLC procedure as described previously (Mergaert et al., 1993). Computer analysis of the resulting profiles was performed as described by Heyrman et al. (1999).

Phenotypic characterization. The strains were characterized phenotypically by using the methods of Logan \& Berkeley (1984); other characteristics were determined, and the data analysed numerically, as described by Logan et al. (2000). Vegetative cells and sporangia were observed by phase-contrast microscopy for the presence of motile cells, chains of cells, curved rods, rods with tapered ends, vacuoles, spores, swollen sporangia, parasporal crystals, parasporal bodies, spores of ellipsoidal, cylindrical or spherical shape and spores positioned terminally, subterminally or centrally/paracentrally; the strains were also examined for casein and starch hydrolysis by using the methods of Gordon et al. (1973). Maximum and minimum growth temperatures were determined by incubating $10 \mathrm{ml}$ TSA cultures in water baths set to 30,40 and $50^{\circ} \mathrm{C}$; $\mathrm{pH}$ ranges for growth were determined using $10 \mathrm{ml}$ TSA cultures adjusted to $\mathrm{pH} 4 \cdot 0,5 \cdot 0,6 \cdot 0,7 \cdot 0$, $8 \cdot 0,9 \cdot 0,10 \cdot 0,11 \cdot 0$ and $12 \cdot 0$. Both series were examined for turbidity at $24 \mathrm{~h}$ intervals. Anaerobic growth was tested for by incubating cultures on TSA plates in a GasPak jar (BBL), with aerobically incubated plates as controls.

\section{RESULTS AND DISCUSSION}

\section{Genomic fingerprinting}

Partial 16S rDNA sequencing, including the hypervariant region for Bacillus (Goto et al., 2000), and (GTG) 5 genomic fingerprinting were performed on the soil isolates. The latter technique revealed important genomic variability among the isolates, which might reflect the heterogeneity of the soil habitat. Comparison of the two techniques allowed grouping of consistent clusters of genomically closely related isolates (Fig. 1), from which representative strains were selected for further DNA-DNA relatedness experiments. In the partial $16 \mathrm{~S}$ rDNA sequence clustering, four groups of isolates could be delineated that showed a high degree of internal sequence similarity $(>99 \cdot 8 \%)$. These clusters are denoted A, B, C and D in Fig. 1(a); adjacent outliers of these clusters are denoted by lower-case letters. The clustering of the $(\mathrm{GTG})_{5}$ fingerprints (Fig. 1b) is generally in good agreement with that obtained by sequencing. With the exception of IDA1746, all isolates belonging to the major $16 \mathrm{~S}$ groups, A-D, also group together in the (GTG) $)_{5}$ clustering. As might be expected, the rep-PCR patterns are much more heterogeneous and thus clusters $\mathrm{A}, \mathrm{B}, \mathrm{C}$ and $\mathrm{D}$ were cut off at low Pearson's correlation percentages, 
Table 1. Strains used in this study, isolation conditions and overview of genomic methods used for characterization

Strain designations: IDA, isolate Drentse A, original strain designations (Felske et al., 1999); R-, Research Collection, Laboratorium voor Microbiologie, Universiteit Gent, Ghent, Belgium; LMG, BCCM/LMG Bacteria Collection Laboratorium voor Microbiologie, Universiteit Gent, Ghent, Belgium.

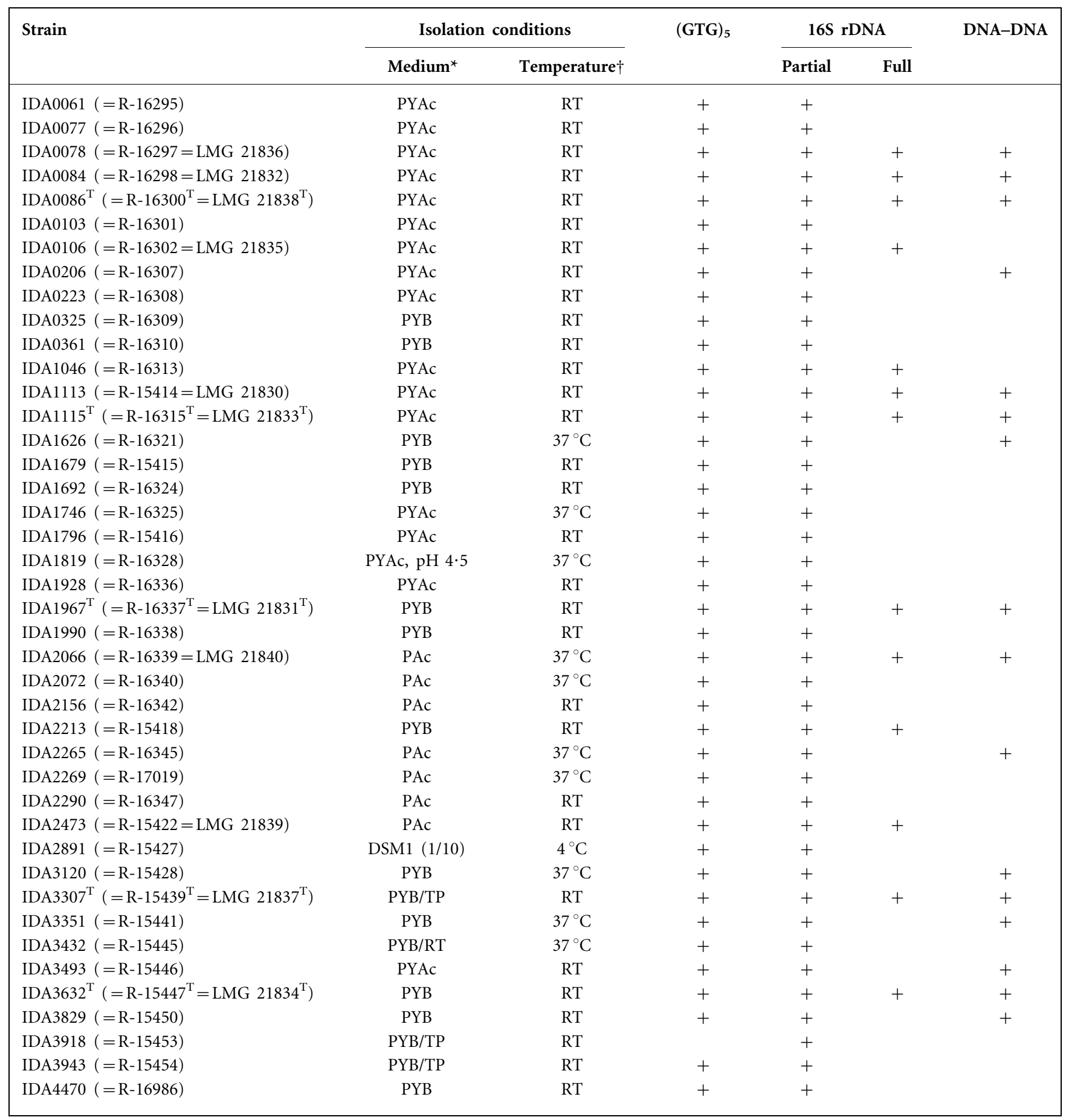

${ }^{*}$ Incubation media: P, mineral medium (Pichinoty et al., 1977); Y, added yeast extract $\left(2 \mathrm{~g}^{-1}\right)$; B, added sodium benzoate $\left(2 \mathrm{~g} \mathrm{l}^{-1}\right)$; Ac, added sodium acetate $\left(2 \mathrm{~g} \mathrm{l}^{-1}\right)$; $\mathrm{TP}$, added $\mathrm{K}_{2} \mathrm{TeO}_{3}\left(1 \cdot 6 \mathrm{mg} \mathrm{l}^{-1}\right)$ and phenethyl alcohol $(0 \cdot 25 \%, \mathrm{v} / \mathrm{v})$.

$\dagger \mathrm{RT}$, Room temperature $\left(\sim 20^{\circ} \mathrm{C}\right)$. 


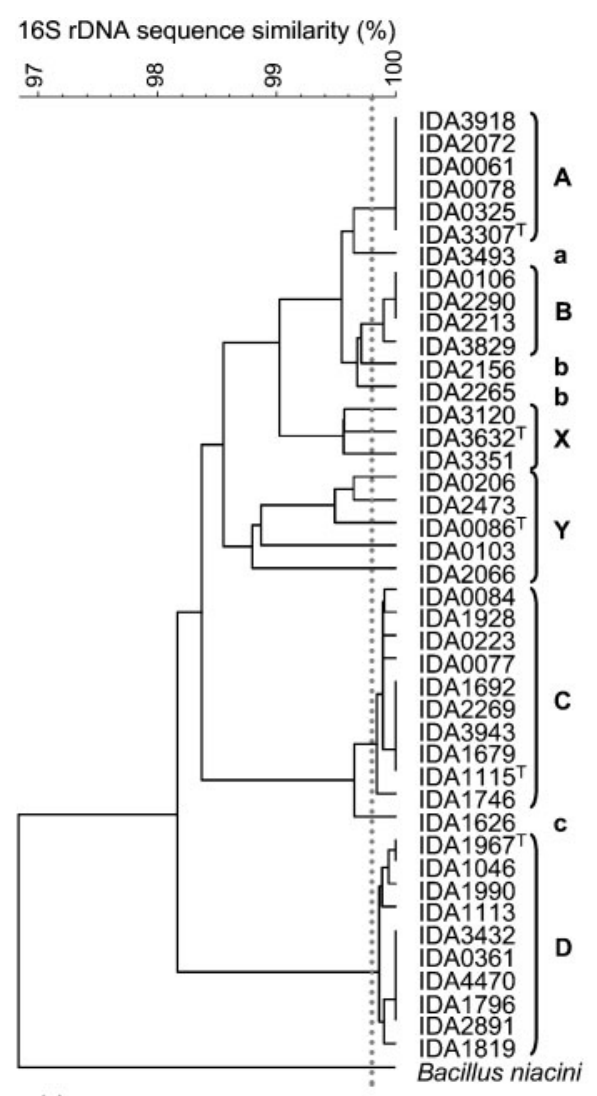

(a)

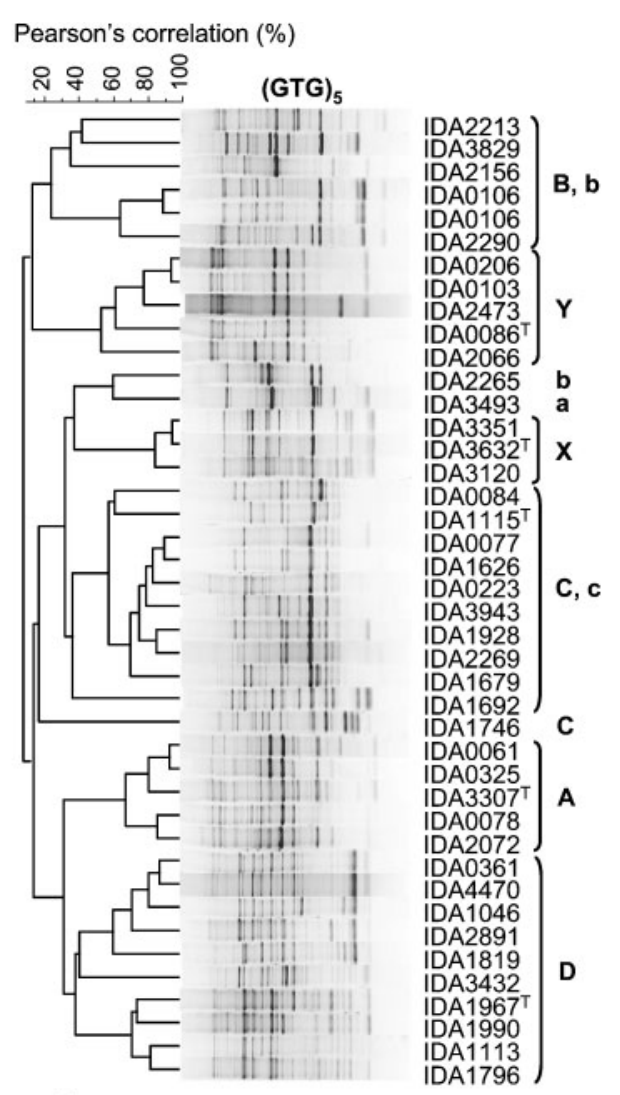

(b)

Fig. 1. Grouping based on partial $16 \mathrm{~S}$ rDNA sequences (a) and normalized (GTG) 5 -PCR patterns (b) of the Drentse $A$ grassland isolates. Clusters A, B, C and D were delineated at $99.8 \%$ partial sequence similarity. Outliers in the immediate vicinity of these clusters are indicated by lower-case letters. Clusters $X$ and $Y$ comprise isolates that are more heterogeneous in partial rDNA sequence, although their intracluster rep-PCR patterning is similar. IDA0106 was used to test the reproducibility of $(\mathrm{GTG})_{5}$ analysis (PCR and gel electrophoresis). The very weak (GTG) 5 pattern from IDA3918 was excluded from the clustering.

respectively $67,24,36$ and $41 \%$. Furthermore, two clusters (X and Y; Fig. 1) could be delineated at a Pearson's correlation level above $50 \%$ in the rep-PCR analysis, showing internal partial sequence similarities definitely below $99 \cdot 8 \%$.

A more complete 16S rDNA sequence of representative strains of the different groups was analysed. By using a FASTA search (Pearson \& Lipman, 1988), B. niacini (AB021194) was found to possess the most closely related sequence of the Bacillus species with validly published names in the database. Representatives of groups A, B, C, D, X and Y showed respective sequence similarities to this entry of $97 \cdot 8,97 \cdot 9,98 \cdot 4,99 \cdot 0,98 \cdot 0$ and $98 \cdot 2 \%$. Furthermore, the representatives of groups $C$ and $D$ showed sequence similarities to B. fumarioli (AJ210056) of $97 \cdot 1$ and $97 \cdot 4 \%$. $16 \mathrm{~S}$ rDNA sequence similarities to all other species with validly published names in the EMBL database were below $97 \%$. In a neighbour-joining tree (Saitou \& Nei, 1987), the sequences form a distinct lineage, with $B$. niacini and B. fumarioli as the closest relatives (Fig. 2).
Representative strains of clusters $\mathrm{A}-\mathrm{D}, \mathrm{X}$ and $\mathrm{Y}$ together with their closest outliers were analysed in DNA-DNA reassociation experiments (Table 2). Generally recommended and accepted criteria for delineating bacterial species state that strains with a DNA-DNA relatedness below $70 \%$, as measured by hybridization, or with $16 \mathrm{~S}$ rDNA sequence dissimilarity above $3 \%$ are considered as belonging to separate species (Wayne et al., 1987; Stackebrandt \& Goebel, 1994; Stackebrandt et al., 2002). Yet, bacterial strains with a difference in $16 \mathrm{~S}$ rDNA sequence of less than $3 \%$ cannot be allocated to the same species without support from DNA-DNA relatedness studies. The DNA-DNA relatedness of the representative strains with respect to $B$. niacini $\mathrm{LMG} 16677^{\mathrm{T}}$ was low $(<30 \%)$, while the internal group values were high (>80\%; Table 2). Strains IDA3493, IDA2265 and IDA1626, which respectively group in rep-PCR analysis outside clusters A, B and C, could also clearly be attributed to the respective clusters on the basis of DNA-DNA relatedness values. Clusters $\mathrm{C}, \mathrm{D}$ and $\mathrm{Y}$ are genotypically distinct from all other groups, with DNA relatedness values below $35 \%$; 


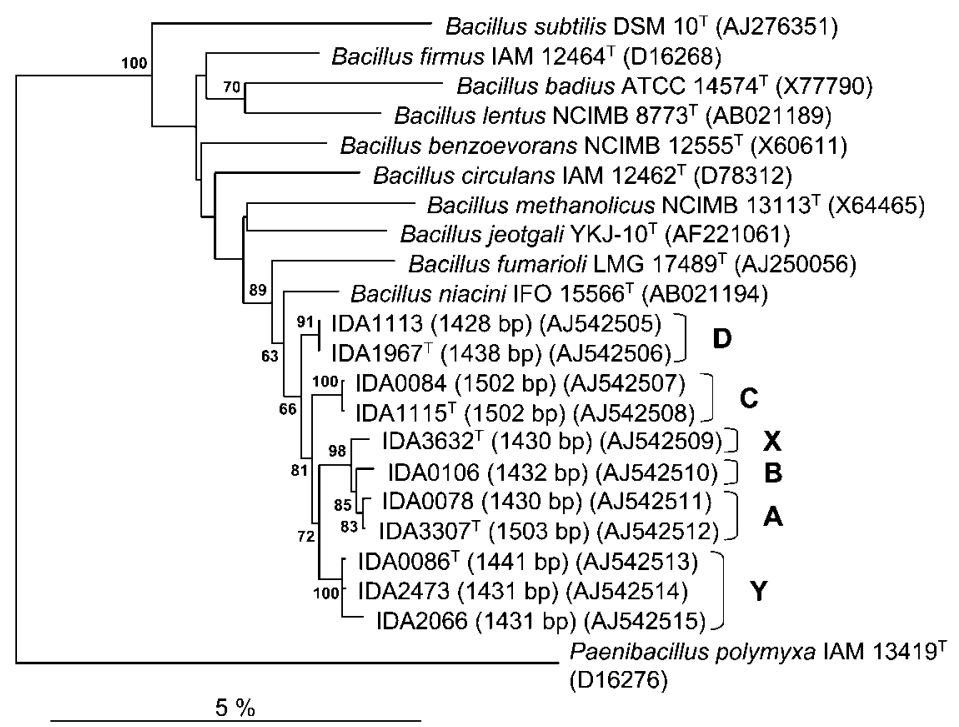

Fig. 2. Phylogenetic positions based on neighbour-joining of the 16S rDNA sequences of representative Drentse $A$ grassland isolates, among related Bacillus species. Paenibacillus polymyxa was used as an outgroup. Bootstrap values (expressed as percentages of 1000 replications) greater than $60 \%$ are shown at branch points.

groups $\mathrm{C}, \mathrm{D}$ and $\mathrm{Y}$ will be further denoted as Bacillus bataviensis sp. nov., Bacillus drentensis sp. nov. and Bacillus soli sp. nov., respectively. The DNA relatedness values between representatives of clusters A and B and the closely related strains IDA3493 and IDA2265 were between 68 and $73 \%$. These values are an indication that the isolates belong to the same species, something which was supported by further phenotypic analysis, and thus the group will be further denoted as Bacillus novalis sp. nov. Overall DNA hybridization values of these strains with respect to representatives of cluster $\mathrm{X}$ are in the range 55-63\%. Although these values are just below the threshold for species delineation, the two groups were found to be phenotypically distinct from each other (see below), which supports separate species status for the two groups. Group X strains are proposed as Bacillus vireti sp. nov.

\section{Fatty acid analysis}

Overall, the fatty acid profiles of the grassland isolates are quite similar. However, on the basis of quantitative (percentage) distribution of the dominant fatty acids, two groups of isolates can be recognized: one group contains B. novalis (groups $\mathrm{A}$ and $\mathrm{B})$, B. vireti $(\mathrm{X})$ and B. soli (Y) isolates, while another group contains $B$. bataviensis $(\mathrm{C})$ and B. drentensis (D) strains. This second group differs from the

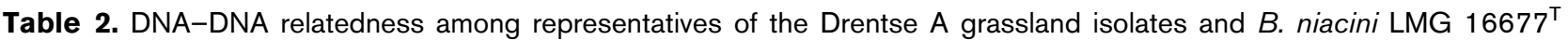

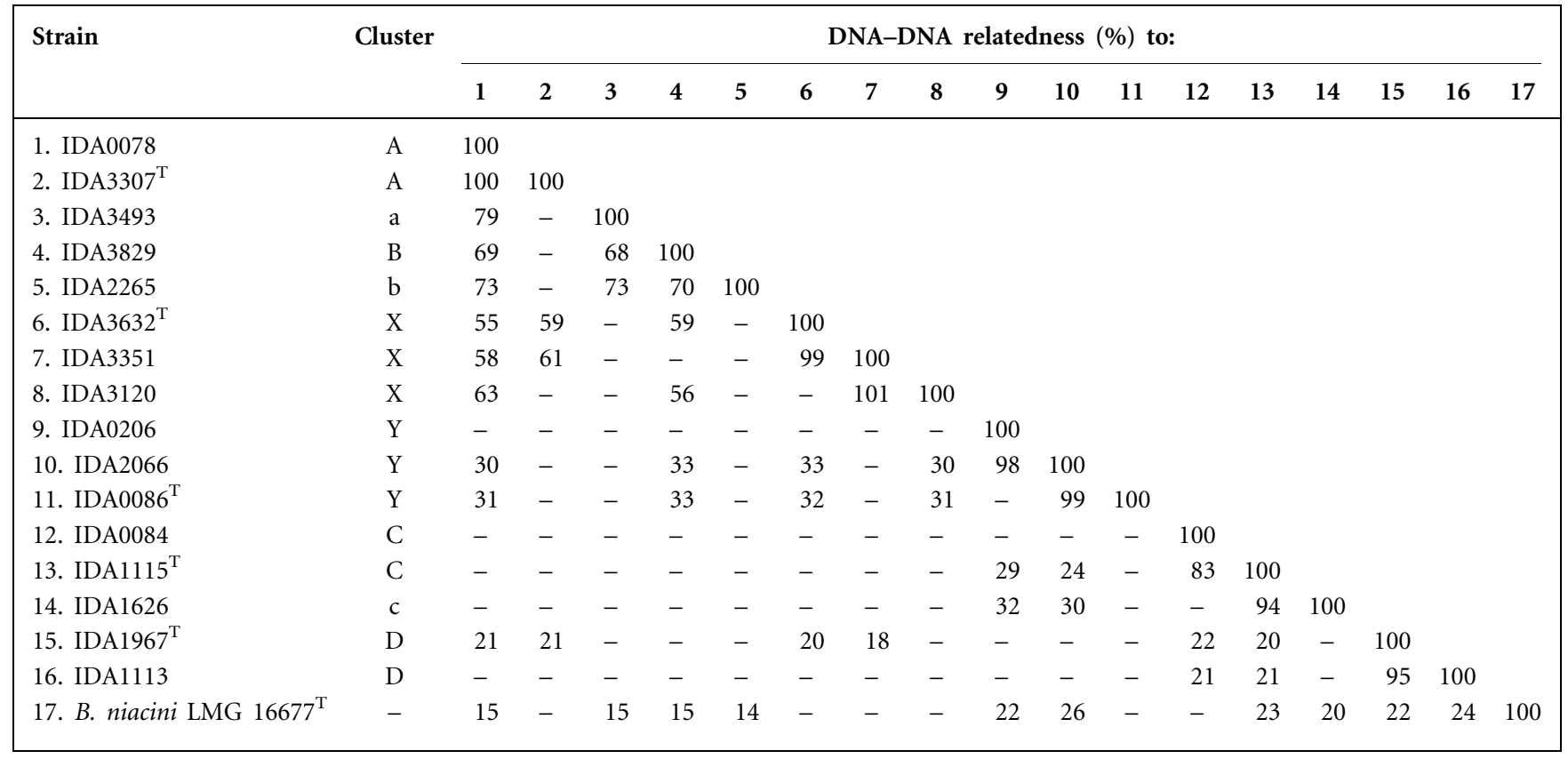


Table 3. Comparison of mean fatty acid profiles of the five novel taxa as measured by GC of fatty acid methyl esters

Data are mean percentages of total fatty acids \pm SD. Only fatty acids accounting for at least $1.0 \%$ of the total fatty acid content are listed. The summed feature comprises iso- $\mathrm{C}_{17: 1} \mathrm{I}$ and/or anteiso- $\mathrm{C}_{17: 1} \mathrm{~B}$.

\begin{tabular}{|c|c|c|c|c|c|}
\hline Fatty acid & $\begin{array}{c}\text { B. novalis } \\
\text { (13 isolates) }\end{array}$ & $\begin{array}{c}\text { B. vireti } \\
\text { (3 isolates) }\end{array}$ & $\begin{array}{c}\text { B. soli } \\
\text { (5 isolates) }\end{array}$ & $\begin{array}{l}\text { B. bataviensis } \\
\text { (11 isolates) }\end{array}$ & $\begin{array}{l}\text { B. drentensis } \\
\text { (10 isolates) }\end{array}$ \\
\hline iso- $\mathrm{C}_{14: 0}$ & $5 \cdot 3 \pm 1 \cdot 9$ & $3 \cdot 1 \pm 1 \cdot 2$ & $3 \cdot 3 \pm 0 \cdot 5$ & $6 \cdot 9 \pm 1 \cdot 1$ & $8 \cdot 7 \pm 2 \cdot 5$ \\
\hline $\mathrm{C}_{14: 0}$ & $3 \cdot 0 \pm 1 \cdot 3$ & $1 \cdot 6 \pm 0 \cdot 2$ & $<1 \cdot 0$ & $1 \cdot 5 \pm 0 \cdot 6$ & $1 \cdot 4 \pm 1 \cdot 3$ \\
\hline iso- $\mathrm{C}_{15: 0}$ & $43 \cdot 9 \pm 5 \cdot 4$ & $47 \cdot 1 \pm 3 \cdot 5$ & $42 \cdot 9 \pm 2 \cdot 3$ & $36 \cdot 9 \pm 4 \cdot 3$ & $32 \cdot 2 \pm 4 \cdot 2$ \\
\hline anteiso- $\mathrm{C}_{15: 0}$ & $31 \cdot 0 \pm 2 \cdot 6$ & $33 \cdot 6 \pm 2 \cdot 0$ & $33 \cdot 5 \pm 1 \cdot 9$ & $20 \cdot 5 \pm 3 \cdot 0$ & $21 \cdot 8 \pm 5 \cdot 6$ \\
\hline $\mathrm{C}_{16: 1} \omega 7 c$ alcohol & $1 \cdot 7 \pm 0 \cdot 8$ & $<1 \cdot 0$ & $2 \cdot 4 \pm 0 \cdot 6$ & $2 \cdot 3 \pm 0 \cdot 8$ & $3 \cdot 1 \pm 0 \cdot 8$ \\
\hline iso- $\mathrm{C}_{16: 0}$ & $2 \cdot 7 \pm 1 \cdot 3$ & $2 \cdot 5 \pm 1 \cdot 8$ & $1 \cdot 4 \pm 0 \cdot 6$ & $2 \cdot 4 \pm 0 \cdot 7$ & $2 \cdot 1 \pm 1 \cdot 0$ \\
\hline $\mathrm{C}_{16: 1} \omega 11 c$ & $3 \cdot 2 \pm 1 \cdot 1$ & $1 \cdot 5 \pm 0 \cdot 1$ & $3 \cdot 2 \pm 0 \cdot 8$ & $11 \cdot 3 \pm 3 \cdot 7$ & $13 \cdot 2 \pm 5 \cdot 5$ \\
\hline $\mathrm{C}_{16: 0}$ & $4 \cdot 8 \pm 2 \cdot 2$ & $3 \cdot 8 \pm 1 \cdot 0$ & $1 \cdot 6 \pm 1 \cdot 1$ & $7 \cdot 7 \pm 3 \cdot 2$ & $3 \cdot 4 \pm 1 \cdot 6$ \\
\hline iso- $\mathrm{C}_{17: 1} \omega 10 c$ & $<1 \cdot 0$ & $<1 \cdot 0$ & $4 \cdot 1 \pm 1 \cdot 1$ & $1 \cdot 7 \pm 0 \cdot 5$ & $4 \cdot 5 \pm 1 \cdot 4$ \\
\hline Summed feature & $<1 \cdot 0$ & $<1 \cdot 0$ & $1 \cdot 8 \pm 0 \cdot 5$ & $<1 \cdot 0$ & $<1 \cdot 0$ \\
\hline iso- $\mathrm{C}_{17: 0}$ & $<1 \cdot 0$ & $2 \cdot 0 \pm 0 \cdot 8$ & $2 \cdot 6 \pm 0 \cdot 7$ & $1 \cdot 4 \pm 0 \cdot 8$ & $2 \cdot 6 \pm 0 \cdot 6$ \\
\hline anteiso- $\mathrm{C}_{17: 0}$ & $1 \cdot 9 \pm 0 \cdot 7$ & $2 \cdot 7 \pm 0 \cdot 6$ & $1 \cdot 5 \pm 0 \cdot 4$ & $1 \cdot 1 \pm 0 \cdot 4$ & $1 \cdot 1 \pm 0 \cdot 3$ \\
\hline $\mathrm{C}_{18: 1} \omega 9 c$ & $<1 \cdot 0$ & $<1 \cdot 0$ & $<1 \cdot 0$ & $1 \cdot 3 \pm 0 \cdot 8$ & $1 \cdot 8 \pm 1 \cdot 1$ \\
\hline $\mathrm{C}_{18: 0}$ & $<1 \cdot 0$ & $<1 \cdot 0$ & $<1 \cdot 0$ & $2 \cdot 7 \pm 1 \cdot 4$ & $1 \cdot 3 \pm 0 \cdot 9$ \\
\hline
\end{tabular}

first by having smaller amounts of the dominant fatty acids iso- $\mathrm{C}_{15: 0}$ and anteiso- $\mathrm{C}_{15: 0}$ and by having moderate amounts of $\mathrm{C}_{16: 1} \omega 11 c$ (Table 3).

\section{Cultural and physiological characteristics}

In the numerical analysis of API (bioMérieux) tests and other phenotypic characteristics (data not shown), strains representing clusters A and B (both attributed to B. novalis) were not separable, which was in accordance with the hybridization data. B. novalis strains showed an $S_{\mathrm{G}}$ (Gower similarity coefficient) of $90 \%$ and their nearest neighbours in the analysis were strains of Bacillus oleronius and isolates of Bacillus shackletonii from Candlemas Island (Logan et al., 2004 ), at $82.5 \% S_{\mathrm{G}}$. Thus, B. novalis forms a group that is phenotypically distinct from other Bacillus species and from the other Drentse A isolates. For the B. vireti isolates, inconsistent results were obtained. Although IDA $3632^{\mathrm{T}}$ and IDA3351 showed quite high similarity $\left(92.5 \% S_{\mathrm{G}}\right)$ and joined with isolates of Bacillus cereus at only $85 \% S_{\mathrm{G}}$, strain IDA3120 showed high similarity $\left(92.5 \% S_{\mathrm{G}}\right)$ with B. soli. Such heterogeneous phenotypic patterns were unexpected, since (GTG) $)_{5}$-PCR and DNA-DNA hybridization showed that the three isolates were genotypically very homogeneous, but, as IDA3120 generally showed weak reactions, it is probable that the standard test medium used did not provide suitable growth conditions for all of the strains, resulting in a less stable phenotypic pattern. All isolates of B. soli, on the other hand, showed very high similarity to each other $\left(95 \% S_{\mathrm{G}}\right)$, but were only separated from the type strain of Bacillus horikoshii by a difference of $5 \%$ in similarity, and from the type strain of Bacillus firmus by a $7 \cdot 5 \%$ similarity difference. Therefore, although this group is phenotypically distinct and homogeneous, the characteristics used in this study may not always allow its reliable separation from phenotypically similar species. Isolates belonging to $B$. bataviensis clustered quite loosely and then merged with $B$. novalis and the $B$. oleronius and B. shackletonii clusters at $80 \% S_{\mathrm{G}}$. B. bataviensis, therefore, shows greater heterogeneity than $B$. novalis, being less well separated from the other Bacillus species. B. drentensis isolates merged at $87.5 \% S_{\mathrm{G}}$, but were separated from representatives of Bacillus lentus (including the type strain) by a difference of only $5 \%$ in similarity. Therefore, although $B$. drentensis appears to form a coherent group in this analysis, it is not easily distinguishable from $B$. lentus by these phenotypic tests.

The phenotypic profiles used to distinguish the five groups of Drentse A isolates from each other and from phenotypically similar Bacillus species are shown in Table 4. Many tests give weak or variable reactions, so discrimination depends upon patterns of features, rather than on the presence or absence of features characteristic of an individual taxon.

\section{Description of Bacillus novalis sp. nov.}

Bacillus novalis (no.va'lis. L. gen. n. novalis of fallow land).

Cells are Gram-positive, facultatively anaerobic, motile, slightly curved, round-ended rods $(0 \cdot 6-1 \cdot 2 \mu \mathrm{m}$ in diameter), occurring singly and in pairs and occasionally in short chains or filaments. Endospores are mainly ellipsoidal and lie in subterminal, and occasionally paracentral, positions in slightly swollen sporangia (Fig. 3a). When grown on TSA, colonies are raised, with slightly irregular margins and smooth or eggshell-textured surfaces, sometimes with an iridescent centre when viewed by lowpowered microscopy; the consistency is butyrous. Colonies 
Table 4. Differential characteristics of Drentse A grassland isolates and phenotypically related species

Taxa: 1, B. novalis sp. nov.; 2, B. bataviensis sp. nov.; 3, B. drentensis sp. nov.; 4, B. vireti sp. nov.; 5, B. soli sp. nov.; 6, B. niacini (data from Nagel \& Andreesen, 1991); 7, B. oleronius; 8, B. firmus; 9, B. lentus. Data were from this study unless indicated otherwise. Symbols: ,$+>85 \%$ positive; $+/ \mathrm{W}$, positive or weakly positive; $(+), 75-84 \%$ positive or weakly positive; - , $<15 \%$ positive or weakly positive; $(-), 16-25 \%$ positive or weakly positive; $\mathrm{V}$, results vary between strains; W, always weak. ND, Not determined. All grassland isolates investigated in this study gave positive results for hydrolysis of aesculin and for acid production from $\mathrm{N}$-acetyl-D-glucosamine, D-fructose, D-glucose and maltose. All strains gave negative results for arginine dihydrolase, lysine decarboxylase, ornithine decarboxylase, citrate utilization, hydrogen sulfide production, urease, tryptophan deaminase, indole production and acid production from D-arabinose, L-arabinose, D-arabitol, L-arabitol, dulcitol, erythritol, 2-keto-D-gluconate, methyl D-xyloside, L-sorbose, D-tagatose, xylitol and L-xylose.

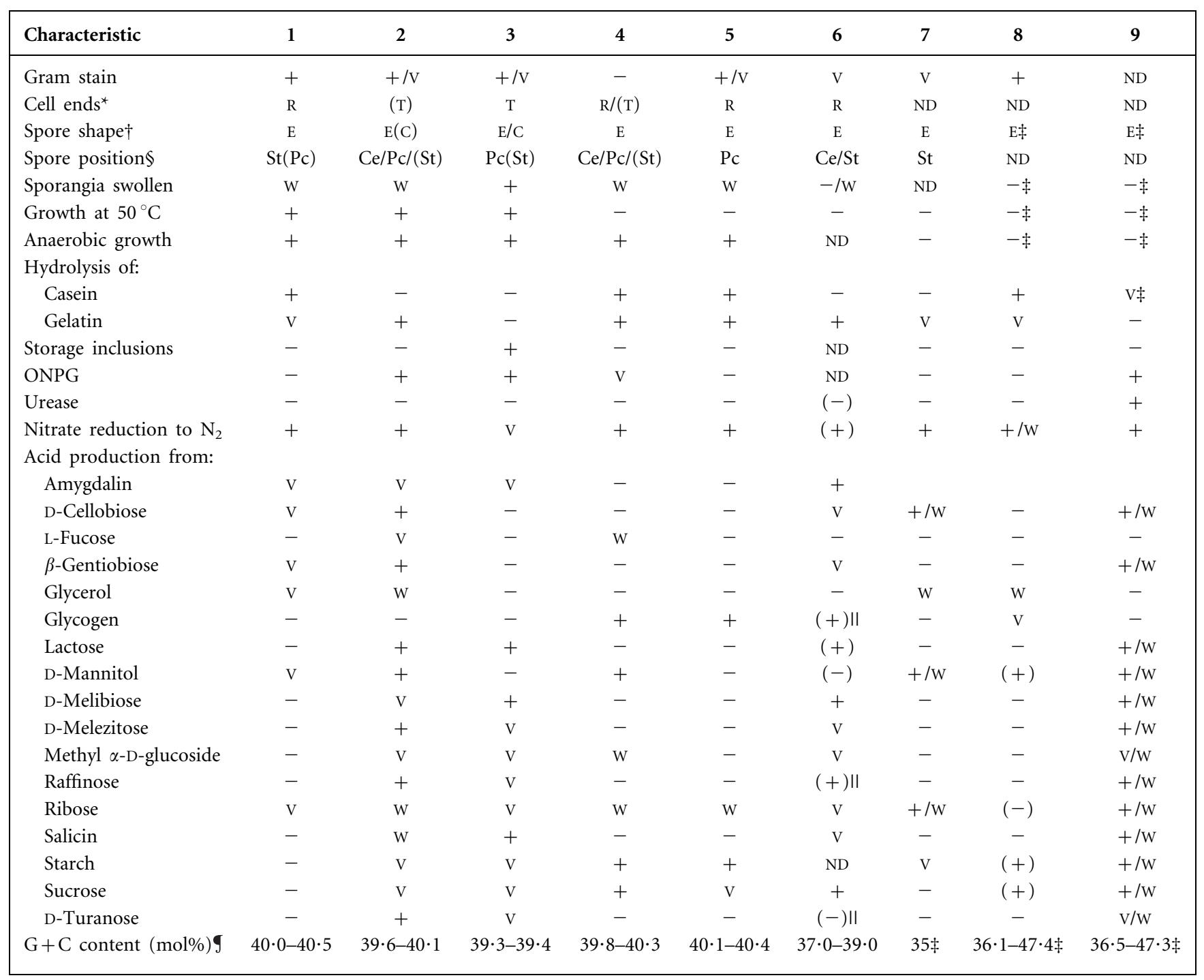

${ }^{\star} \mathrm{R}$, Rounded; T, tapered; (T), slightly tapered.

$\dagger \mathrm{C}$, Circular; E, ellipsoidal.

¥Data from Kuhnigk et al. (1995) for B. oleronius and from Claus \& Berkeley (1986) for B. firmus and B. lentus.

$\S$ Ce, Central; St, subterminal; Pc, paracentral.

IIType strain DSM $2923^{\mathrm{T}}$ was the only strain that gave a different result.

SDetermined for B. novalis IDA0078, IDA2265, IDA3307 ${ }^{\mathrm{T}}$, IDA3493 and IDA3829, B. bataviensis IDA0084, IDA1115 ${ }^{\mathrm{T}}$ and IDA1626, B. drentensis IDA1113 and IDA $1967^{\mathrm{T}}$, B. vireti IDA3120, IDA3351 and IDA3632 ${ }^{\mathrm{T}}$ and B. soli IDA0086 ${ }^{\mathrm{T}}$, IDA0206 and IDA2066.

are cream-coloured and produce a light-brown pigment that diffuses into the agar. Optimal growth occurs at $30-40{ }^{\circ} \mathrm{C}$; the maximum growth temperature lies between 50 and $55^{\circ} \mathrm{C}$. The minimum $\mathrm{pH}$ for growth lies between $4 \cdot 0$ and $5 \cdot 0$, the optimum $\mathrm{pH}$ is $7 \cdot 0-9 \cdot 0$ and the maximum $\mathrm{pH}$ lies between $9 \cdot 5$ and $10 \cdot 0$. Casein is hydrolysed. In the API $20 \mathrm{E}$ 

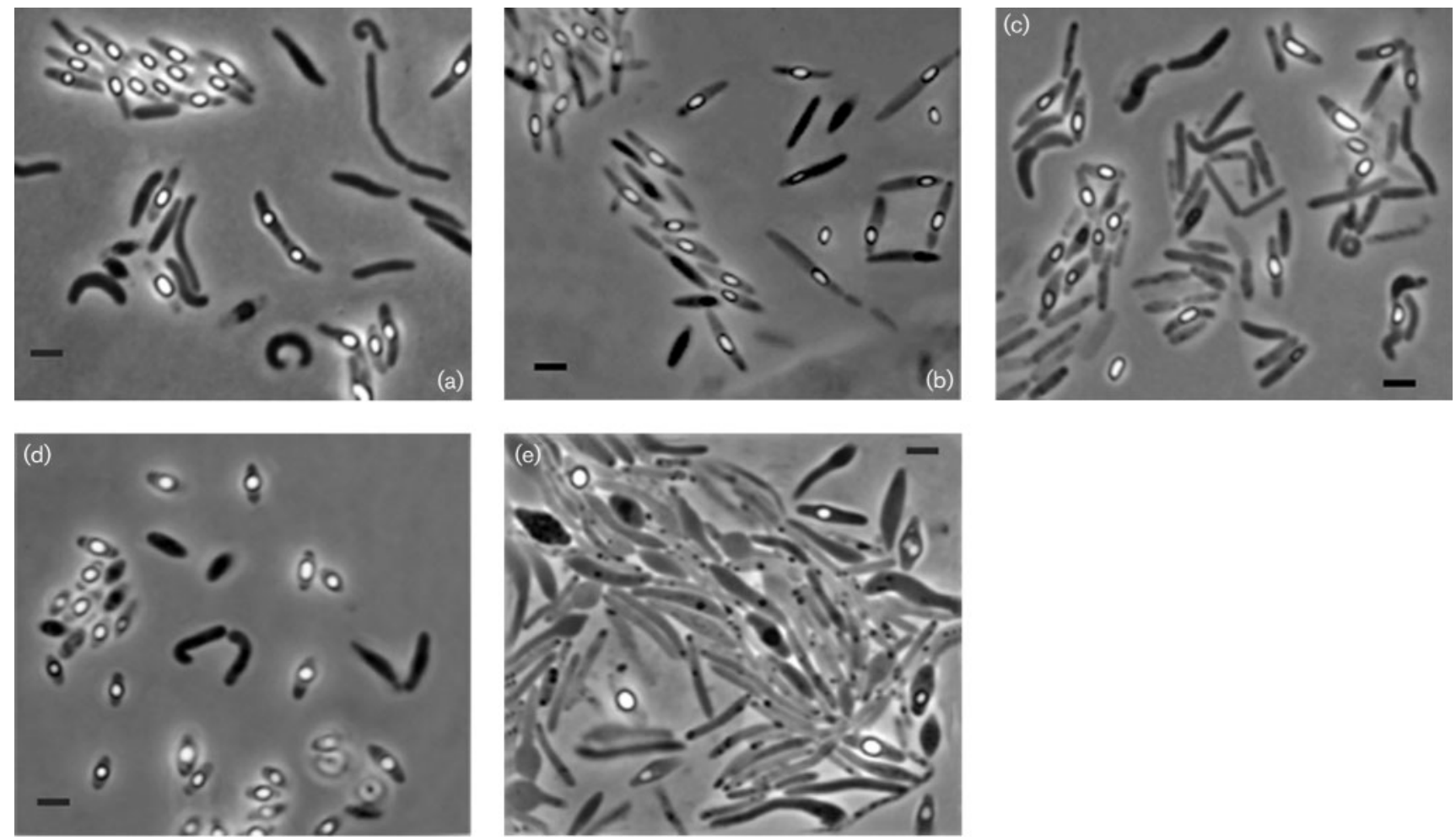

Fig. 3. Photomicrographs of sporangia and vegetative cells of (a) B. novalis sp. nov. LMG $21837^{\top}$, (b) B. vireti sp. nov. LMG $21834^{\top}$, (c) B. soli sp. nov. LMG $21838^{\top}$, (d) B. bataviensis sp. nov. LMG $21833^{\top}$ and (e) B. drentensis sp. nov. LMG $21831^{\top}$. Bars, $3 \mu \mathrm{m}$.

strip, the Voges-Proskauer reaction is negative, gelatin is hydrolysed by most strains and nitrate reduction is positive (sometimes weakly); reactions for ONPG hydrolysis, arginine dihydrolase, lysine decarboxylase, ornithine decarboxylase, citrate utilization, hydrogen sulfide production, urease, tryptophan deaminase and indole production are negative. Aesculin hydrolysis is positive in the API $50 \mathrm{CH}$ gallery. Acid without gas is produced (weakly by some strains) from the following carbohydrates in the API $50 \mathrm{CH}$ gallery, using $\mathrm{CHB}$ suspension medium (bioMérieux): $\mathrm{N}$-acetyl-D-glucosamine, D-fructose, galactose (always weak), D-glucose, maltose, D-mannose and D-trehalose. The following reactions are variable between strains, and, when positive, are usually weak: amygdalin, arbutin, D-cellobiose, $\beta$-gentiobiose, gluconate, glycerol, 5-keto-Dgluconate, D-lyxose, D-mannitol, ribose, sorbitol, D-xylose. Acid is not produced from the following carbohydrates: D-arabinose, L-arabinose, D-arabitol, L-arabitol, dulcitol, erythritol, D-fucose, L-fucose, glycogen, inulin, 2-keto-Dgluconate, lactose, D-melezitose, D-melibiose, meso-inositol, methyl $\alpha$-D-glucoside, methyl $\alpha$-D-mannoside, methyl D-xyloside, raffinose, rhamnose, salicin, L-sorbose, starch, sucrose, D-tagatose, D-turanose, xylitol, D-xylose and $\mathrm{L}$-xylose. The major cellular fatty acids are iso- $\mathrm{C}_{15: 0}$ and anteiso- $\mathrm{C}_{15: 0}$, respectively present at levels of about 44 and $31 \%$ of the total fatty acid content. The following fatty acids are present to at least $1 \%$ : iso- $\mathrm{C}_{14: 0}, \mathrm{C}_{14: 0}, \mathrm{C}_{16: 1} \omega 7 \mathrm{c}$ alcohol, iso- $\mathrm{C}_{16: 0}, \mathrm{C}_{16: 1} \omega 11 \mathrm{c}, \mathrm{C}_{16: 0}$ and anteiso- $\mathrm{C}_{17: 0}$. For the strains tested (Table 4), the $\mathrm{G}+\mathrm{C}$ content is $40 \cdot 0-40 \cdot 5 \mathrm{~mol} \%$. Isolated from soil (Drentse A agricultural research area, The Netherlands).

In the variable reactions listed above, the type strain, LMG $21837^{\mathrm{T}}\left(=\mathrm{R}-15439^{\mathrm{T}}=\mathrm{IDA} 3307^{\mathrm{T}}=\mathrm{DSM} 15603^{\mathrm{T}}\right)$, was positive for amygdalin (weak), D-cellobiose (weak), $\beta$-gentiobiose (weak), D-mannitol (weak), sorbitol and Dxylose. The $\mathrm{G}+\mathrm{C}$ content for the type strain is $40.5 \mathrm{~mol} \%$.

\section{Description of Bacillus vireti sp. nov.}

Bacillus vireti (vi.re'ti. L. gen. n. vireti of the field).

Cells are Gram-negative, facultatively anaerobic, motile, slightly curved, round-ended rods $(0 \cdot 6-0.9 \mu \mathrm{m}$ in diameter) occurring singly and in pairs (Fig. 3b). Cells do not produce endospores on TSA supplemented with $\mathrm{MnSO}_{4}$, but sporulate on B. fumarioli agar at $\mathrm{pH} 7$ after $48 \mathrm{~h}$. Endospores are ellipsoidal, lie in central, paracentral and sometimes subterminal positions and may swell the sporangia slightly; the ends of the sporangia may be slightly tapered. After 3 days growth on TSA, colonies are up to $4 \mathrm{~mm}$ in diameter, circular, raised, with entire edges and dark-cream in colour. The surface has an eggshell-like texture and the biomass is of loose consistency. The optimum temperature for growth is $30^{\circ} \mathrm{C}$ and the 
maximum growth temperature is $40-45^{\circ} \mathrm{C}$. The minimum $\mathrm{pH}$ for growth is $4 \cdot 0-5 \cdot 0$ and the optimum and maximum $\mathrm{pH}$ values for growth are in the range $7 \cdot 0-7 \cdot 5$. Casein is hydrolysed. In the API $20 \mathrm{E}$ strip, gelatin is hydrolysed and nitrate reduction is positive; ONPG hydrolysis is variable; reactions for arginine dihydrolase, lysine decarboxylase, ornithine decarboxylase, citrate utilization, hydrogen sulfide production, urease, tryptophan deaminase, indole production and the Voges-Proskauer test are negative. Hydrolysis of aesculin is positive in the API $50 \mathrm{CH}$ gallery. Acid without gas is produced from the following carbohydrates in the API $50 \mathrm{CH}$ gallery, using the $\mathrm{CHB}$ suspension medium: $\mathrm{N}$-acetyl-D-glucosamine, D-fructose, L-fucose (weak), galactose (weak), D-glucose, glycogen, maltose, D-mannitol, D-mannose, methyl $\alpha$-D-glucoside (weak), ribose (weak), starch, sucrose and D-trehalose. The following reactions are variable between strains and, when positive, are usually weak: gluconate, meso-inositol, methyl $\alpha$-D-mannoside, rhamnose. Acid is not produced from the following carbohydrates: adonitol, amygdalin, D-arabinose, L-arabinose, D-arabitol, L-arabitol, arbutin, D-cellobiose, dulcitol, erythritol, D-fucose, $\beta$-gentiobiose, glycerol, inulin, 2-keto-D-gluconate, 5-keto-D-gluconate, lactose, D-lyxose, D-melezitose, D-melibiose, methyl D-xyloside, raffinose, salicin, sorbitol, L-sorbose, D-tagatose, D-turanose, xylitol and D-xylose and L-xylose. The major cellular fatty acids are iso- $\mathrm{C}_{15: 0}$ and anteiso- $\mathrm{C}_{15: 0}$, respectively present at about 47 and $34 \%$. The following fatty acids are present to at least $1 \%$ : iso- $\mathrm{C}_{14: 0}, \mathrm{C}_{14: 0}$, iso- $\mathrm{C}_{16: 0}, \mathrm{C}_{16: 1} \omega 11 c, \mathrm{C}_{16: 0}$, iso- $\mathrm{C}_{17: 0}$ and anteiso- $\mathrm{C}_{17: 0}$. For the strains tested (Table 4), the $\mathrm{G}+\mathrm{C}$ content is $39 \cdot 8-40 \cdot 3 \mathrm{~mol} \%$. Isolated from soil (Drentse A agricultural research area, The Netherlands).

In the variable reactions listed above, the type strain, LMG $21834^{\mathrm{T}}\left(=\mathrm{R}-15447^{\mathrm{T}}=\mathrm{IDA} 3632^{\mathrm{T}}=\mathrm{DSM} 15602^{\mathrm{T}}\right)$, was weak for gluconate and methyl $\alpha$-D-mannoside and negative for meso-inositol and rhamnose. The $\mathrm{G}+\mathrm{C}$ content of the type strain is $\sim 40 \cdot 2 \mathrm{~mol} \%$.

\section{Description of Bacillus soli sp. nov.}

Bacillus soli (so'li. L. gen. n. soli of soil).

Cells are Gram-positive or Gram-variable, facultatively anaerobic, motile, round-ended rods $(0 \cdot 6-1 \cdot 2 \mu \mathrm{m}$ in diameter), sometimes curved, occurring as single cells, in pairs and in chains. Endospores are ellipsoidal, lie paracentrally and may swell the sporangia (Fig. 3c). On TSA, colonies are butyrous, cream-coloured, low and slightly umbonate, with entire margins and glossy or eggshell-textured surfaces. The optimum growth temperature is $30{ }^{\circ} \mathrm{C}$ and the maximum growth temperature is between 40 and $45^{\circ} \mathrm{C}$. The minimum $\mathrm{pH}$ for growth lies between $4 \cdot 0$ and $5 \cdot 0$, the optimum is $7 \cdot 0-8 \cdot 0$ and the maximum lies between $9 \cdot 0$ and $9 \cdot 5$. Casein is hydrolysed. In the API 20E strip, gelatin is hydrolysed and nitrate reduction is positive; reactions for ONPG hydrolysis, arginine dihydrolase, lysine decarboxylase, ornithine decarboxylase, citrate utilization, hydrogen sulfide production, urease, tryptophan deaminase, indole production and the Voges-Proskauer test are negative. Hydrolysis of aesculin is positive in the API $50 \mathrm{CH}$ gallery. Acid without gas is produced from the following carbohydrates in the API 50CH gallery, using CHB suspension medium: $N$-acetylD-glucosamine, D-fructose, D-glucose, glycogen, maltose (weak), D-mannose, ribose (weak), starch and D-trehalose (weak). The following reactions are variable between strains and, when positive, are usually weak: galactose and sucrose. Acid is not produced from the following carbohydrates: adonitol, amygdalin, D-arabinose, L-arabinose, D-arabitol, L-arabitol, arbutin, D-cellobiose, dulcitol, erythritol, $\mathrm{D}$-fucose, L-fucose, $\beta$-gentiobiose, glycerol, inulin, 2-ketoD-gluconate, 5-keto-D-gluconate, lactose, D-lyxose, Dmannitol, D-melezitose, D-melibiose, methyl $\alpha$-D-glucoside, methyl D-xyloside, raffinose, salicin, sorbitol, L-sorbose, D-tagatose, D-turanose, xylitol, D-xylose and L-xylose. The major cellular fatty acids are iso- $\mathrm{C}_{15: 0}$ and anteiso- $\mathrm{C}_{15: 0}$, respectively present at about 43 and $34 \%$. The following fatty acids are present to at least $1 \%$ : iso- $\mathrm{C}_{14: 0}, \mathrm{C}_{16: 1} \omega 7 \mathrm{c}$ alcohol, iso- $\mathrm{C}_{16: 0}, \mathrm{C}_{16: 1} \omega 11 c, \mathrm{C}_{16: 0}$, iso- $\mathrm{C}_{17: 1} \omega 10 c$, iso$\mathrm{C}_{17: 0}$ and anteiso- $\mathrm{C}_{17: 0}$. For the strains tested (Table 4), the $\mathrm{G}+\mathrm{C}$ content is $40 \cdot 1-40 \cdot 4 \mathrm{~mol} \%$. Isolated from soil (Drentse A agricultural research area, The Netherlands).

In the variable reactions listed above, the type strain, LMG $21838^{\mathrm{T}}\left(=\mathrm{R}-16300^{\mathrm{T}}=\mathrm{IDA} 0086^{\mathrm{T}}=\mathrm{DSM} 15604^{\mathrm{T}}\right)$, was positive for galactose (weak) and negative for sucrose. The $\mathrm{G}+\mathrm{C}$ content of the type strain is $40 \cdot 1 \mathrm{~mol} \%$.

\section{Description of Bacillus bataviensis sp. nov.}

Bacillus bataviensis (ba.ta.vi.en'sis. L. masc. adj. bataviensis pertaining to Batavia, the name Julius Caesar gave to The Netherlands).

Gram-positive or variable (at $24 \mathrm{~h}$ ), facultatively anaerobic, motile, slightly tapered rods $(0 \cdot 7-1 \cdot 2 \mu \mathrm{m}$ in diameter) occurring singly, in pairs and in short chains. Endospores are mainly ellipsoidal but may be spherical, and lie centrally, paracentrally and occasionally subterminally, in slightly swollen sporangia (Fig. 3d). Colonies grown on TSA are butyrous, cream-coloured and produce a light-brown pigment that diffuses into the agar; they are slightly raised and umbonate, have regular margins and have smooth or rough, eggshell-textured surfaces. The optimum temperature for growth is $30^{\circ} \mathrm{C}$ and the maximum growth temperature lies between 50 and $55^{\circ} \mathrm{C}$. The minimum $\mathrm{pH}$ for growth lies between 4.0 and $6 \cdot 0$, the optimum $\mathrm{pH}$ is $7 \cdot 0-8 \cdot 0$ and the maximum $\mathrm{pH}$ lies between $9 \cdot 5$ and $10 \cdot 0$. Casein is not hydrolysed. In the API 20E strip, ONPG hydrolysis is positive, gelatin is hydrolysed by most strains and nitrate reduction is positive; the Voges-Proskauer reaction is negative and reactions for arginine dihydrolase (one strain positive), lysine decarboxylase, ornithine decarboxylase, citrate utilization, hydrogen sulfide production, urease, tryptophan deaminase and indole production are negative. Hydrolysis of aesculin is positive in the API $50 \mathrm{CH}$ gallery. Acid without gas is produced from the 
following carbohydrates in the API 50CH gallery, using CHB suspension medium: $N$-acetyl-D-glucosamine, Dcellobiose, $\mathrm{D}$-fructose, galactose, $\beta$-gentiobiose, $\mathrm{D}$-glucose, glycerol (weak), lactose, maltose, D-mannitol, D-mannose, D-melezitose, raffinose, ribose (weak), salicin (weak), D-trehalose and D-turanose. The following reactions are variable between strains and, when positive, are usually weak: amygdalin, arbutin, L-fucose, inulin, D-melibiose, methyl $\alpha$-D-glucoside, methyl $\alpha$-D-mannoside, starch and sucrose. Acid is not produced from the following carbohydrates: adonitol, D-arabinose, L-arabinose, D-arabitol, L-arabitol, dulcitol, erythritol, D-fucose, gluconate, glycogen, 2-keto-D-gluconate, 5-keto-D-gluconate, D-lyxose, meso-inositol, methyl D-xyloside, rhamnose, sorbitol, L-sorbose, D-tagatose, xylitol, D-xylose and L-xylose. The major cellular fatty acids are iso- $\mathrm{C}_{15: 0}$ and anteiso- $\mathrm{C}_{15: 0}$, respectively present at about 37 and $21 \%$, while $\mathrm{C}_{16: 1} \omega 11 \mathrm{c}$ accounts for about $11 \%$ of the total fatty acids. The following fatty acids are present to at least $1 \%$ : iso- $\mathrm{C}_{14: 0}$, $\mathrm{C}_{14: 0}, \mathrm{C}_{16: 1} \omega 7 c$ alcohol, iso- $\mathrm{C}_{16: 0}, \mathrm{C}_{16: 0}$, iso- $\mathrm{C}_{17: 1} \omega 10 c$, iso- $\mathrm{C}_{17: 0}$, anteiso- $\mathrm{C}_{17: 0}, \mathrm{C}_{18: 1} \omega 9 \mathrm{c}$ and $\mathrm{C}_{18: 0}$. For the strains tested (Table 4), the $\mathrm{G}+\mathrm{C}$ content is $39 \cdot 6-40 \cdot 1 \mathrm{~mol} \%$. Isolated from soil (Drentse A agricultural research area, The Netherlands).

In the variable reactions, the type strain, LMG $21833^{\mathrm{T}}(=\mathrm{R}-$ $16315^{\mathrm{T}}=\mathrm{IDA} 1115^{\mathrm{T}}=\mathrm{DSM} 15601^{\mathrm{T}}$ ), was positive but weak for arbutin, L-fucose, inulin, D-melibiose, methyl $\alpha$-Dglucoside, methyl $\alpha$-D-mannoside and sucrose and negative for amygdalin and starch. The $\mathrm{G}+\mathrm{C}$ content for the type strain is $40 \cdot 1 \mathrm{~mol} \%$.

\section{Description of Bacillus drentensis sp. nov.}

Bacillus drentensis (dren.ten'sis. N.L. masc. adj. drentensis of Drente, a province in The Netherlands).

Cells are Gram-positive or Gram-variable, facultatively anaerobic, motile, tapered rods $(0 \cdot 6-1 \cdot 2 \mu \mathrm{m}$ in diameter $)$ occurring singly and in pairs. Cells show pleomorphism (narrow and broad cells, the latter showing swellings) and produce intracellular storage inclusions on TSA. Endospores are spherical or ellipsoidal and lie in paracentral or occasionally subterminal positions in swollen sporangia (Fig. 3e). Colonies are slightly convex with regular margins when small and sometimes wrinkled with irregular margins and prominent centres when larger. Colonies are creamcoloured and produce a brownish soluble pigment; the consistency is butyrous, with an eggshell-like surface texture. The optimum temperature for growth is $30^{\circ} \mathrm{C}$ and the maximum growth temperature lies between 50 and $55^{\circ} \mathrm{C}$. The minimum $\mathrm{pH}$ for growth lies between 5.5 and $6 \cdot 0$, the optimum $\mathrm{pH}$ is $7 \cdot 0-8 \cdot 0$ and the maximum $\mathrm{pH}$ lies between $9 \cdot 5$ and $10 \cdot 0$. Casein is not hydrolysed. In the API 20E strip, ONPG hydrolysis is positive, the VogesProskauer reaction is variable (most strains negative, positive strains weak) and the nitrate reduction is variable; reactions for arginine dihydrolase, lysine decarboxylase, ornithine decarboxylase, citrate utilization, hydrogen sulfide production, urease, tryptophan deaminase, indole production and gelatin hydrolysis are negative. Hydrolysis of aesculin is positive in the API 50CH gallery. Acid without gas is produced from the following carbohydrates in the API 50CH gallery, using CHB suspension medium: $N$-acetyl-Dglucosamine, D-fructose, D-glucose (some strains, including the type strain, weak), lactose, maltose, D-melibiose and salicin (some strains, including the type strain, weak). The following reactions are variable between strains and, when positive, are usually weak: amygdalin, arbutin, galactose, gluconate, inulin, D-mannose, D-melezitose, methyl $\alpha$-Dglucoside, raffinose, ribose, starch, sucrose, D-trehalose, D-turanose and D-xylose. Acid is not produced from the following carbohydrates: adonitol, D-arabinose, L-arabinose, D-arabitol, L-arabitol, D-cellobiose, dulcitol, erythritol, D-fucose, L-fucose, $\beta$-gentiobiose, glycerol, glycogen, 2-keto-D-gluconate, 5-keto-D-gluconate, D-lyxose, D-mannitol, meso-inositol, methyl $\alpha$-D-mannoside, methyl D-xyloside, rhamnose, sorbitol, L-sorbose, D-tagatose, xylitol and Lxylose. The major cellular fatty acids are iso- $\mathrm{C}_{15: 0}$ and anteiso- $\mathrm{C}_{15: 0}$, respectively present at about 32 and $22 \%$, while $\mathrm{C}_{16: 1} \omega 11 \mathrm{c}$ accounts for about $13 \%$ of the total fatty acids. The following fatty acids are present to at least $1 \%$ : iso- $\mathrm{C}_{14: 0}, \mathrm{C}_{14: 0}, \mathrm{C}_{16: 1} \omega 7 c$ alcohol, iso- $\mathrm{C}_{16: 0}, \mathrm{C}_{16: 0}$, iso$\mathrm{C}_{17: 1} \omega 10 c$, iso- $\mathrm{C}_{17: 0}$, anteiso- $\mathrm{C}_{17: 0}, \mathrm{C}_{18: 1} \omega 9 c$ and $\mathrm{C}_{18: 0}$. For the strains tested (Table 4), the $\mathrm{G}+\mathrm{C}$ content is $39 \cdot 3-39 \cdot 4 \mathrm{~mol} \%$. Isolated from soil (Drentse A agricultural research area, The Netherlands).

In the variable reactions, the type strain, $\mathrm{LMG} 21831^{\mathrm{T}}(=\mathrm{R}-$ $16337^{\mathrm{T}}=\mathrm{IDA} 1967^{\mathrm{T}}=$ DSM $\left.15600^{\mathrm{T}}\right)$, was positive for inulin, D-mannose, D-melezitose, raffinose (weak), ribose (weak), starch (weak), sucrose and D-turanose (weak) and negative for amygdalin, arbutin, galactose, gluconate, methyl $\alpha-\mathrm{D}$ glucoside, D-trehalose and D-xylose. The G $+\mathrm{C}$ content for the type strain is $39 \cdot 4 \mathrm{~mol} \%$.

\section{ACKNOWLEDGEMENTS}

The authors acknowledge the financial support of the European Commission (grant EU-QLK3-2000-01678) for the project BACREX (http://www.bacrex.com/_bacrex_/). We are most grateful to bioMérieux for providing API materials and for supporting M. R.-D.

\section{REFERENCES}

Claus, D. \& Berkeley, R. C. W. (1986). Genus Bacillus Cohn 1872. In Bergey's Manual of Systematic Bacteriology, vol. 2, pp. 1105-1139. Edited by P. H. A. Sneath, N. S. Mair, M. E. Sharpe \& J. G. Holt. Baltimore: Williams \& Wilkins.

Ezaki, T., Hashimoto, Y. \& Yabuuchi, E. (1989). Fluorometric deoxyribonucleic acid-deoxyribonucleic acid hybridization in microdilution wells as an alternative to membrane filter hybridization in which radioisotopes are used to determine genetic relatedness among bacterial strains. Int J Syst Bacteriol 39, 224-229.

Felske, A. \& Akkermans, A. D. L. (1998). Spatial homogeneity of abundant bacterial 16S rRNA molecules in grassland soils. Microb Ecol 36, 31-36. 
Felske, A., Wolterink, A., Van Lis, R. \& Akkermans, A. D. L. (1998). Phylogeny of the main bacterial 16S rRNA sequences in Drentse A grassland soils (The Netherlands). Appl Environ Microbiol 64, 871-879.

Felske, A., Wolterink, A., van Lis, R., de Vos, W. M. \& Akkermans, A. D. L. (1999). Searching for predominant soil bacteria: $16 \mathrm{~S}$ rDNA cloning versus strain cultivation. FEMS Microbiol Ecol 30, 137-145.

Gordon, R. E., Haynes, W. C. \& Pang, C. H.-N. (1973). Media and methods. In The Genus Bacillus, Agriculture Handbook no. 427, pp. 3-14. Washington, DC: US Department of Agriculture.

Goto, K., Omura, T., Hara, Y. \& Sadaie, Y. (2000). Application of the partial 16S rDNA sequence as an index for rapid identification of species in the genus Bacillus. J Gen Appl Microbiol 46, 1-8.

Heyndrickx, M., Vauterin, L., Vandamme, P., Kersters, K. \& De Vos, P. (1996). Applicability of combined amplified ribosomal DNA restriction analysis (ARDRA) patterns in bacterial phylogeny and taxonomy. J Microbiol Methods 26, 247-259.

Heyrman, J. \& Swings, J. (2001). 16S rDNA sequence analysis of bacterial isolates from biodeteriorated mural paintings in the Servilia tomb (necropolis of Carmona, Seville, Spain). Syst Appl Microbiol 24, 417-422.

Heyrman, J., Mergaert, J., Denys, R. \& Swings, J. (1999). The use of fatty acid methyl ester analysis (FAME) for the identification of heterotrophic bacteria present on three mural paintings showing severe damage by microorganisms. FEMS Microbiol Lett 181, 55-62. Kuhnigk, T., Borst, E. M., Breunig, A., Konig, H., Collins, M. D., Hutson, R. A. \& Kämpfer, P. (1995). Bacillus oleronius sp. nov., a member of the hindgut flora of the termite Reticulitermes santonensis (Feytaud). Can J Microbiol 41, 699-706.

Logan, N. A. \& Berkeley, R. C. W. (1984). Identification of Bacillus strains using the API system. J Gen Microbiol 130, 1871-1882.

Logan, N. A., Lebbe, L., Hoste, B. \& 7 other authors (2000). Aerobic endospore-forming bacteria from geothermal environments in northern Victoria Land, Antarctica, and Candlemas Island, South Sandwich archipelago, with the proposal of Bacillus fumarioli sp. nov. Int J Syst Evol Microbiol 50, 1741-1753.

Logan, N. A., Lebbe, L., Verhelst, A., Goris, J., Forsyth, G., Rodríguez-Díaz, M., Heyndrickx, M. \& De Vos, P. (2004). Bacillus shackletonii sp. nov., from volcanic soil on Candlemas Island, South Sandwich archipelago. Int J Syst Evol Microbiol 54 (in press).

Marmur, J. (1961). A procedure for the isolation of deoxyribonucleic acid from micro-organisms. J Mol Biol 3, 208-218.

Mergaert, J., Verdonck, L. \& Kersters, K. (1993). Transfer of Erwinia ananas (synonym, Erwinia uredovora) and Erwinia stewartii to the genus Pantoea emend. as Pantoea ananas (Serrano 1928) comb. nov. and Pantoea stewartii (Smith 1898) comb. nov., respectively, and description of Pantoea stewartii subsp. indologenes subsp. nov. Int J Syst Bacteriol 43, 162-173.

Mesbah, M., Premachandran, U. \& Whitman, W. B. (1989). Precise measurement of the $\mathrm{G}+\mathrm{C}$ content of deoxyribonucleic acid by high-performance liquid chromatography. Int J Syst Bacteriol 39, 159-167.

Nagel, M. \& Andreesen, J. R. (1991). Bacillus niacini sp. nov., a nicotinate-metabolizing mesophile isolated from soil. Int $J$ Syst Bacteriol 41, 134-139.

Pearson, W. R. \& Lipman, D. J. (1988). Improved tools for biological sequence comparison. Proc Natl Acad Sci U S A 85, 2444-2448.

Pichinoty, F., Mandel, M., Greenway, B. \& Garcia, J.-L. (1977). Isolation and properties of a denitrifying bacterium related to Pseudomonas lemoignei. Int J Syst Bacteriol 27, 346-348.

Pitcher, D. G., Saunders, N. A. \& Owen, R. J. (1989). Rapid extraction of bacterial genomic DNA with guanidium thiocyanate. Lett Appl Microbiol 8, 151-156.

Rademaker, J. L. W. \& de Bruijn, F. J. (1997). Characterization and classification of microbes by rep-PCR genomic fingerprinting and computer assisted pattern analysis. In DNA Markers: Protocols, Applications and Overviews, pp. 151-171. Edited by G. GaetanoAnollés \& P. M. Gresshoff. New York: Wiley.

Saitou, N. \& Nei, M. (1987). The neighbor-joining method: a new method for reconstructing phylogenetic trees. Mol Biol Evol 4, 406-425.

Stackebrandt, E. \& Goebel, B. M. (1994). Taxonomic note: a place for DNA-DNA reassociation and 16S rRNA sequence analysis in the present species definition in bacteriology. Int J Syst Bacteriol 44, 846-849.

Stackebrandt, E., Frederiksen, W., Garrity, G. M. \& 10 other authors (2002). Report of the ad hoc committee for the re-evaluation of the species definition in bacteriology. Int J Syst Evol Microbiol 52, 1043-1047.

Versalovic, J., Schneider, M., de Bruijn, F. J. \& Lupksi, J. R. (1994). Genomic fingerprinting of bacteria using repetitive sequence-based polymerase chain reaction. Methods Mol Cell Biol 5, 25-40.

Wayne, L. G., Brenner, D. J., Colwell, R. R. \& 9 other authors (1987). International Committee on Systematic Bacteriology. Report of the ad hoc committee on reconciliation of approaches to bacterial systematics. Int J Syst Bacteriol 37, 463-464.

Willems, A., Doignon-Bourcier, F., Goris, J., Coopman, R., de Lajudie, P., De Vos, P. \& Gillis, M. (2001). DNA-DNA hybridization study of Bradyrhizobium strains. Int J Syst Evol Microbiol 51, 1315-1322. 